\title{
Community knowledge of Amorphophallus muelleri Blume: Cultivation and utilization in Central Java, Indonesia
}

\author{
BAIQ FARHATUL WAHIDAH ${ }^{1,2, \boldsymbol{v}}$, NORMA AFIATI $I^{1,3}$, JUMARI $^{4}$ \\ ${ }^{1}$ Doctoral Program in Environmental Science, School of Postgraduate, Universitas Diponegoro, J1. Imam Bardjo No. 5, Semarang City 50241, Central \\ Java, Indonesia. \\ ${ }^{2}$ Department of Biology, Faculty of Science and Technology, Universitas Islam Negeri Walisongo. Jl. Prof. Hamka Ngaliyan Semarang City 50185, \\ Central Java, Indonesia. Tel./Fax. +62-024-76433366, `email: baiqfarhatulwahidah@walisongo.ac.id. \\ ${ }^{3}$ Department of Aquatic Resources, Faculty of Fisheries and Marine Sciences, Universitas Diponegoro, J1. Prof. Soedarto, SH, Tembalang Semarang City \\ 50275, Central Java, Indonesia. \\ ${ }^{4}$ Department of Biology, Faculty of Science and Mathematics Universitas Diponegoro, Jl. Prof. Soedarto, SH, Tembalang Semarang City 50275, Central \\ Java, Indonesia
}

Manuscript received: 15 May 2021. Revision accepted: 16 June 2021.

\begin{abstract}
Wahidah BF, Afiati N, Jumari. 2021. Community knowledge of Amorphophallus muelleri Blume: Cultivation and utilization in Central Java, Indonesia. Biodiversitas 22: 2731-2738. Porang (Amorphophallus muelleri Blume) is a member of the Araceae edible family currently popular on Java island, Indonesia. In the last five years, this plant which has high economic value due to its various benefits as a food plant and medicinal plant has been cultivated in Central Java. This study aims to determine the knowledge of the people in Central Java about porang plant, its cultivation, and its use in people's lives. The method used is a qualitative method by applying data collection techniques through interviews, observation and documentation. Besides general interviews, this study gains more information from some informants whose purposively chosen amongst the respondents as people knowledgeable about porang in general, and in particular A. muelleri. Results showed that people in Central Java do have knowledge about porang plant even though it was not used as food ingredient. Public knowledge about porang cultivation is obtained from various sources including social media and people who strive for porang with success. Therefore, since the community is currently aware of the potential and economic values of porang, they have started to cultivate it. Porang has enormous potential to be developed in the future and provide welfare for the community.
\end{abstract}

Keywords: Amorphophallus muelleri, Central Java, community knowledge, cultivation, porang, utilization

\section{INTRODUCTION}

The Amorphophallus muelleri Blume plant is a member of the taro family (Araceae). This edible Araceae is a native Indonesian plant that grows wild in tropical forests (Susanto 2020). Generally, people in Java know this plant by the name porang. This plant thrives in many lowland areas, mountains, and forests with tall trees (Santosa et al. 2003; Sumarwoto and Maryana 2011). Porang grows among tall plants that live around it, such as teak and sono trees as shelter (Santosa et al. 2018; Lontoh et al. 2019). One of the locations in Java as a place to grow porang is the plateau in Central Java, Indonesia.

Currently, porang plant is popular in Indonesia. In recent years, people have become interested in cultivating porang, particularly on the island of Jawa and more specifically in Central Java. The government also pays great attention to porang cultivation to be propagated into an export commodity (DPRD-Jateng 2020; PemprovJateng 2020; Pertanian-Jateng 2020). The development of porang cultivation is driven by the economic value of the porang tuber and its derivative products. The high glucomannan content in porang tubers makes this plant in great demand, especially by the food and health industry either in domestic or international trade (Wigoeno et al.
2013). According to Shi et al. (2020) glucomannan is a hydrophilic polysaccharide that can be produced from various natural plants. One of the most famous is the glucomannan konjac. In addition, the tubers are also a source of low calories carbohydrates that are rich in fiber, so they are very suitable for dieting. According to Shi et al. (2019), this plant from the Amorphophallus genus is rich in soluble dietary fiber and has long been used as food and traditional medicine in Asian countries. Glucomannan can be an alternative to losing weight and overcoming obesity, especially in adults (Mohammadpour et al. 2020).

Sirotkin (2021) stated that glucomannan contained in tubers of the genus Amorphophallus has the ability to reduce the fat storage process through extra and intracellular mechanisms. Thus, porang cultivation is a very promising business in the future. Derivative products such as shirataki rice are in great demand by the public (Widjaja et al. 2014), since the Amorphophallus tubers act as a "dietary fiber" which may lower blood cholesterol levels (Fang and Wu 2004; Vasques et al. 2008; Chua et al. 2010; Impaprasert et al. 2014; Behera and Ray 2017).

People live and interact with the environment around forests, fields and rice fields by using their local knowledge. Plants can be used as a source of nutrition, medicine and housing needs. In addition, people also use this knowledge to plant and cultivate plants that are 
considered important for life. According to Antweiler (1998), local knowledge means knowledge integrated into a culture originating from a certain area or location. Therefore explains logically the relationship between humans and their environment. This knowledge is emic, which means that what is understood from the perspective of local people is part of a long process of human adaptation to their environment (Purcell 1998). Specifically, local knowledge regarding the environment is also known as Traditional Ecological Knowledge (TEK), which means the whole knowledge and practice of the relationship between living things, including humans and their environment, which is passed down culturally (Berkes 2008). From this knowledge, people make use of the porang plants living around them for welfare purposes.

Many Indonesians, especially the Central Javanese, live from agriculture. Several Indonesian scholars have written public knowledge about Amorphophallus plants. Mutaqin et al. (2020) writes about the use of suweg (A. paeoniifolius) in the Majalengka community of West Java. Similar research was conducted by Hidayat (2019) on suweg that grew under teak plantations. Other research is about the characteristics of glucomannan contained in porang tubers (Yanuriati et al. 2017). Meanwhile, research on local people's knowledge about the A. muelleri species is still very rare, so this article might introduce how the local people know about porang gain a renew.

People in Central Java recognize three other types of Amorphophallus, namely A. campanulatus var. sylvestris (walur), A. variabilis (iles-iles) and A. paeoniifolius (suweg). These types are commonly known to the public by the names porang, ponang, iles-iles, suweg and walur whose names are often exchanged in different regions. For example, in Central Java, porang (A. muelleri) is called iles-iles, in West Java it is called acung (Susanto 2020) and in Madura it is called kruwu (Sugiyama and Santosa 2008). Morphologically, these plants are very similar to one another, so that it is one of other factors causing different local names in different regions.

This study aimed to determine the knowledge of the people of Central Java, Indonesia about the porang plant (A. muelleri), its cultivation and its use in people's lives.

\section{MATERIALS AND METHODS}

\section{Study area}

The research was carried out on communities in the Semarang and its surrounding areas of Central Java Province, Indonesia, i.e., Wonosari Village (Ngaliyan Subdistrict, Semarang City), Nongkosawit Village (Gunungpati Sub-district, Semarang City), Bergas Village (Ungaran Sub-district, Semarang District), Tuntang Village (Tuntang Sub-district, Semarang District), Blotongan Village (Sidorejo Sub-district, Salatiga City), and Watulawang Village (Limbangan Sub-district, Kendal District) (Figure 1).

\section{Procedures}

The method used is a qualitative method that seeks to explore the experience of the people of Semarang and its surroundings about Amorphophallus muelleri Blume (emics), which is then validated using scientific knowledge (ethics). The samples were determined purposively with the criteria of local people who have knowledge and expertise about Amorphophallus. In this study, the number of informants interviewed was 20 people consisting of 7 porang farmers and entrepreneurs, 6 workers in porang agriculture, 6 local communities, and 1 staff from the agriculture and forestry office.
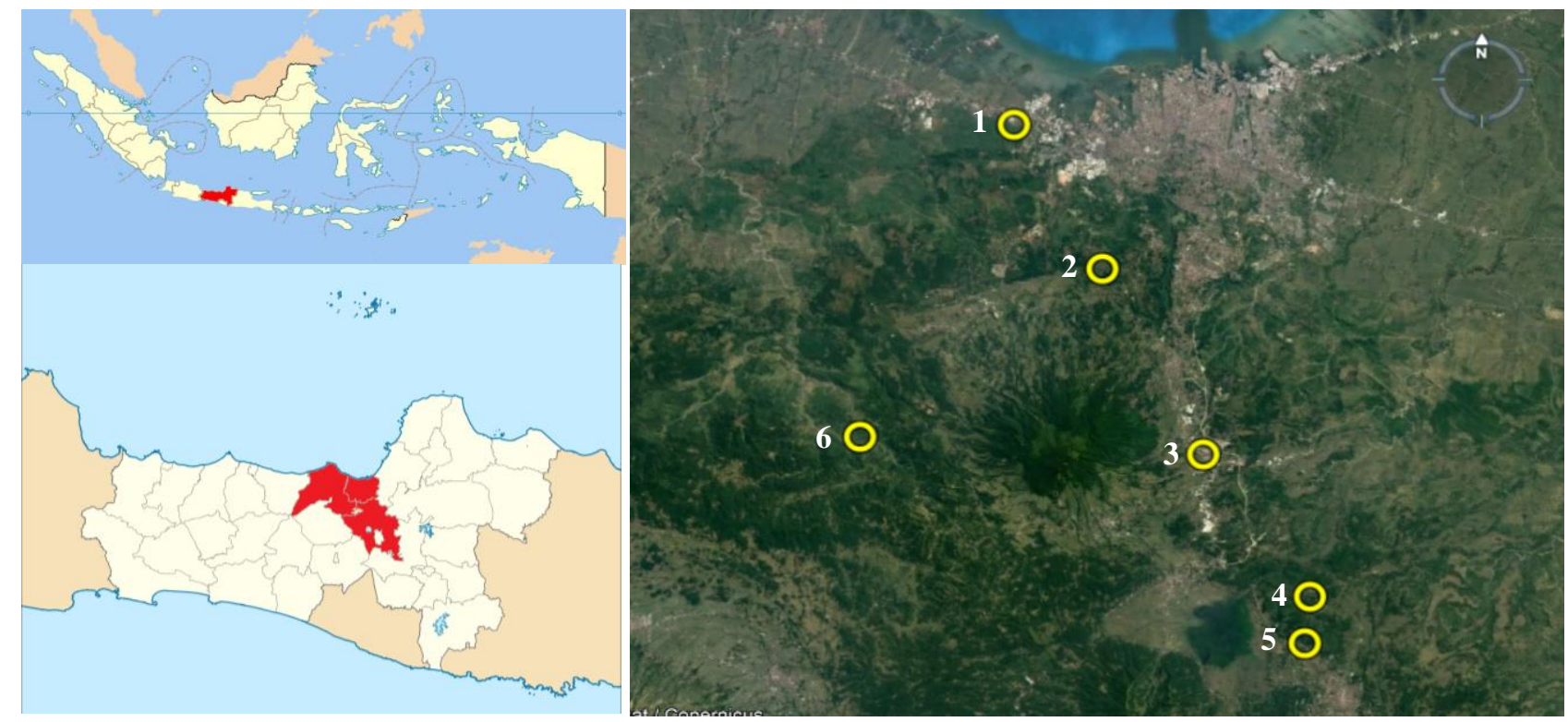

Figure 1. Sampling locations of this study in Semarang and its surrounding areas of Central Java Province, Indonesia, including subdistricts of: 1. Wonosari Village, 2. Nongkosawit Village, 3. Bergas Village, 4. Tuntang Village, 5. Blotongan Village, 6. Watulawang Village, January to February 2021 
Data collection was carried out by using semistructured interviews and field observations. Semistructured interviews were conducted with snowball sampling technique. The key informants in this study were porang farmers from the Limbangan area. The next informant was obtained from the key informant. While the method of observation is carried out by looking at porang plants by conducting field observations of the forest, plantation and local community homes.

\section{RESULTS AND DISCUSSION}

\section{Research location profile}

This research was conducted in several locations to explore people's knowledge about cultivation and utilization of the porang plant (Amorphophallus muelleri Blume). First, Wonosari Village is an area located in Ngaliyan Sub-district, Semarang City. The area and land conditions are very suitable for cultivating porang plants. In Wonosari, farmers cultivate porang and have started his business two years ago. Second, Nongkosawit Village is an area located in Gunungpati Sub-district, Semarang City. In Gunungpati a porang community of ca. 20 members has been established. Third, Bergas Village is located in the mountainous area of Ungaran Sub-district, Semarang District. The land in this region is very fertile, so it is easy to cultivate porang. Fourth, Tuntang Village is located in Tuntang Sub-district, Semarang District. There is a farmer and a porang businessman who cultivates porang on his own land and has several assisted members in this area.

Fifth, Blotongan Village, Sidorejo Sub-district, Salatiga city is located on the Central Java regional route that connects the cities of Semarang and Surakarta. Salatiga is at an altitude of 450-800 meters above sea level (m asl) and is very suitable for cultivating porang. Sixth, Watulawang Village is located in Limbangan Sub-district, Kendal District. The farmers also selling seeds to outside Java, i.e., Aceh, Palembang, Riau, Maluku, Ternate and North Sulawesi. Many people of Watulawang cultivate porang and are members of the assisted farmers.

\section{Community knowledge about porang (A. muelleri)}

According to stories from the local community, the porang plant has been known since the Japanese colonial era. At that time, the Japanese ordered people to collect porang in the forest, either to be sent to Japan or as a daily food ingredient (Saleh et al. 2015). In addition, porang was used as a staple food for forced labor under the leadership of the Japanese colonialists (Romusha). Porang is processed simply into food by boiling. Although porang was not considered food by Indonesians at that time, in Japan porang was a food raw material in traditional food offerings (Mubarok and Santoso 2018; Adachi et al. 2020). Until now, porang plants are still easily found in Indonesia and live wild.

The plant has a characteristic of tuber shape and living at an altitude of 300-600 meters above sea level, is also known by the public as "food for snakes". People attach this identity to these plants to explain that this food is only for animals and is not suitable for human consumption. One of the reasons is because consuming porang can cause itching in the body. This causes porang not to be included in the category of community food. In Javanese society, using terms or proverbs to describe a prohibition is something common. Therefore, people call porang "food for snakes". There are not many research results stating that porang is consumed by the community as part of their traditional diet, except for research on the potential of the porang tuber as a food ingredient in Balinese society (Asih and Kurniawan 2019).

Porang (A. muelleri) is an intercropping plant. In the vicinity of the porang plants, several types of shade plants are usually planted. The purpose of this intercropping is to protect porang from exposure to direct sunlight, because porang cannot grow if the temperature is too hot (direct and excessive sunlight). Other plants that usually shade porang cultivation include banana (Musa paradisiaca), mahogany (Swietenia mahagoni), nutmeg (Myristica fragrans) and sengon trees (Albizia chinensis).

In the past, porang was a wild plant that lived in the forest. Porang has been cultivated in Semarang for the last five years. The results of interviews with informants showed that people in the Semarang and surrounding areas generally had some difficulty distinguishing between porang and other Amorphophallus such as suweg, walur or iles-iles. This is because the morphological characters of these species are very similar to each other in terms of leaves, stems and tubers. From the results of field observations, some porang entrepreneurs deliberately planted other species besides porang as a learning medium for prospective farmers and entrepreneurs. This is very useful since the attention of related agencies to this horticultural plant is still limited. The results of interviews with informants stated that the agriculture agency's attention was still limited to the socialization of porang as a cultivated plant.

\section{Utilization of porang (A. muelleri)}

In addition to its high economic value, the porang plant has considerable potential as a medicinal and food plant. The high glucomannan content makes this plant have the potential as an alternative food that is low in calories and good for health. However, from the results of interviews with informants from the community, no one has ever used the porang plant as a medicinal and food ingredient. Although several informants knew the benefits of porang, it was not commonly consumed by the community. This is somewhat different from the suweg (A. paeoniifolius) which is commonly consumed by people in Semarang and its surroundings. Suweg is consumed with very simple processing, namely by boiling it. The same thing is done by the people of West Java, suweg is used as a snack and for religious rituals (Mutaqin et al. 2020).

According to Shi et al. (2019), the genus of Amorphophallus plant contains plentiful dietary fiber. A. konjac was recorded in Mandarin in $210 \mathrm{BC}$. for the treatment of wounds, tumors and skin diseases (Liu et al. 1998). In addition, A. konjac is said to have anti-obesity, antidiabetic, anti-constipation, anti-hypercholesterolemic 
properties and shows potential as anti-lung cancer, as well as a prebiotic agent, most of which have been validated in various animal models and in vitro tests. Clinical trials on human subjects also support its application as a treatment for diabetes and obesity (Khan and Marya 2019). Other species of the genus Amorphophallus such as $A$. paeoniifolius (Dennst.) Nicolson (syn. A. campanulatus Blume ex Decne) are commonly used in Ayurvedic medicine as well as tribal medicines in India as treating tumors, inflammation, hemorrhoids, vomiting, coughs, bronchitis, asthma, anorexia, dyspepsia, flatulence, colic, anemia and others (Nair et al. 2019). A. paeoniifolius tubers also have a hepatoprotective effect in mice (Hurkadale et al. 2012). Hepatoprotective activity is also found in the tuber A. commutatus. Raj \& Gothandam (2014) stated that the histopathological and biochemical results of the methanol extract of A. commutatus showed hepatoprotective and antioxidant activity which the polyphenol compounds may cause in the extract. In addition, A. paeoniifolius has the potential to cure hemorrhoids through its antiinflammatory and antioxidant properties (Dey et al. 2016).

\section{Community's reasons for planting porang (A. muelleri)}

Based on the results of interviews with local people, there were several reasons why farmers started cultivating porang. These reasons are subjective and of course, differ from one person to another. The following are the reasons people plant porang based on the results of interviews that have been conducted: (i) The success of porang farmers in East Java is the main attraction for porang beginners in Semarang. Information from various media such as YouTube encourages farmers to plant porang. In the past, it was considered as wild food, now porang is considered a blessing plant. Semarang and Central Java are generally considered to be lagging behind in porang cultivation, so many beginners learn from farmers in East Java known to have cultivated porang first; (ii) The COVID-19 pandemic has caused many people to experience layoffs (PHK) so they lose their jobs. This makes some people then look for ways to survive while increasing basic needs. Therefore, the community then decided to start cultivating porang. Especially at this time, the selling price of porang is increasing; (iii) Intrigued by the high value of porang plants. The increasing popularity of porang lately makes many people competing to cultivate it. Entrepreneurs and investors have switched to investing in porang with their large capital. This also made the farmers curious and then planted porang.

\section{Types and process of cultivating porang $(A$. muelleri)}

There are generally two types of porang cultivated by the people of Semarang and its surroundings, namely the green porang (A. muelleri) and black porang or known as black konjac $(A$. konjac). One of the characteristics that distinguish the two porang is the color and motif on the stem. Green porang is dominated by green color with white patches, while black porang is dominated with white spots. Porang only has two colors, in contrast to iles-iles which usually has more than two colors. Farmers already know the difference between porang and other Amorphophallus types from the motif and texture of the stalks. In addition, what distinguishes porang from other Amorphophallus is the presence of bulbil structures between the leaves. When the leaves are perfectly stretched, bulbil, or what farmers knew as "katak", will be seen. This bulbil functions as one of the reproductive organs in porang.

Most of the farmers in Semarang area plant green porang, but recently black porang has become increasingly sought after because it has several advantages, such as the tubers development process is faster, the tubers produced are usually larger and heavier. And if it is dried, the tuber is heavier. Although it does not really matter in terms of price, according to the farmers, there is the potential for black porang to be one of the prime varieties.

The porang plant experiences two growth phases that appear alternately, namely the vegetative growth and generative growth phases. The vegetative phase includes the growth of pseudo leaves and stems (stalks). After some time, these vegetative organs wither and the tubers are dormant. When all the leaves have died, there are still food reserves in the tubers and if the growing environment is supportive, the generative phase will begin, namely the growth of compound flowers which in its development will produce seeds. The seeds produced in this generative phase are called spores by farmers.

For cultivation needs, seeds can come from tubers, bulbils (katak), and seeds (spora) of porang. These organs become seeds of different qualities. Usually, seeds that come from tubers are the best choice because they will produce tubers that are larger in size and weight compared to seeds or bulbils (Figure 2).
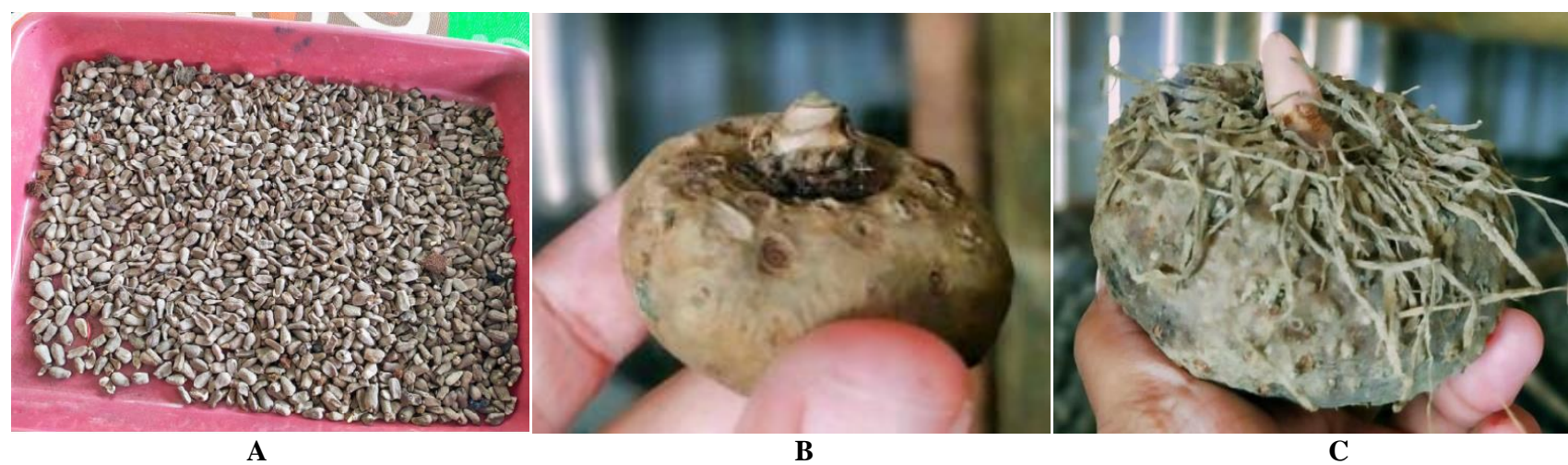

Figure 2. Organs of plant used for reproduction process. A. Seeds spora., B. Bulbil katak., C. Tuber 


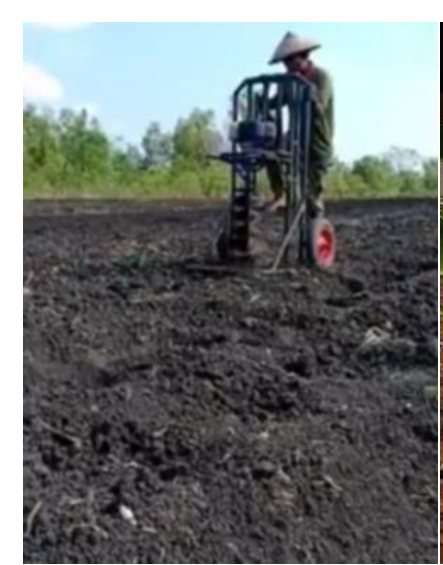

A
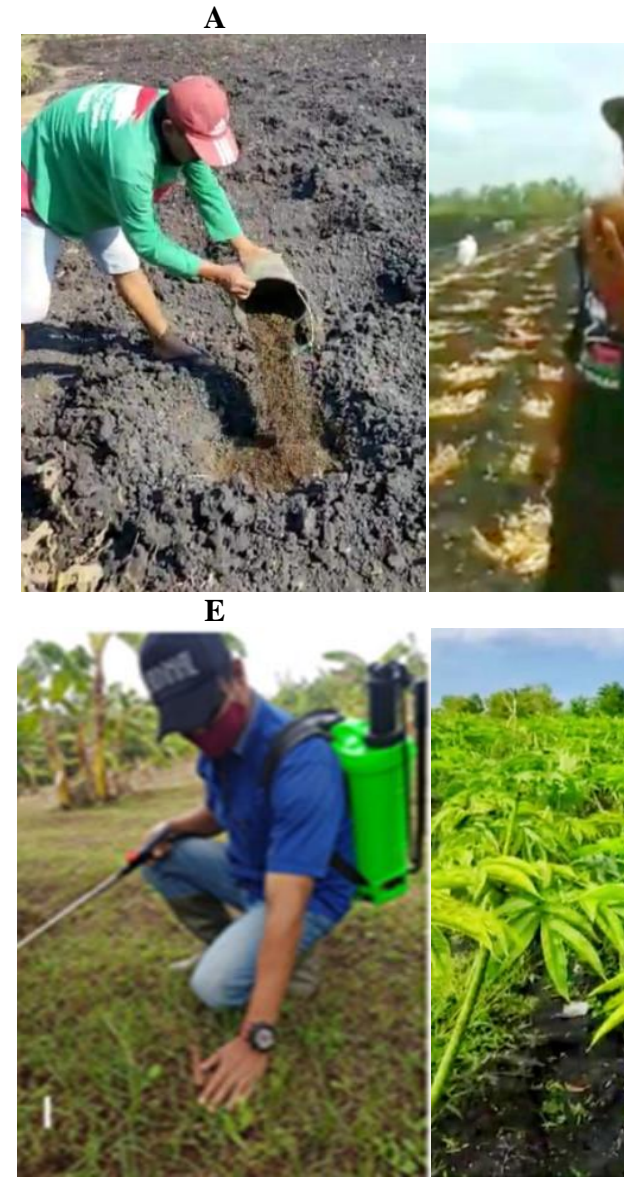

I

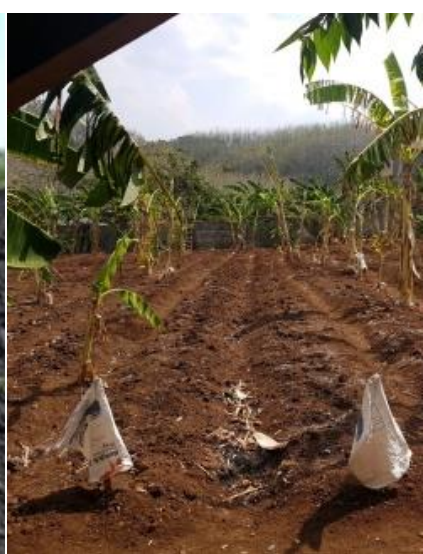

B

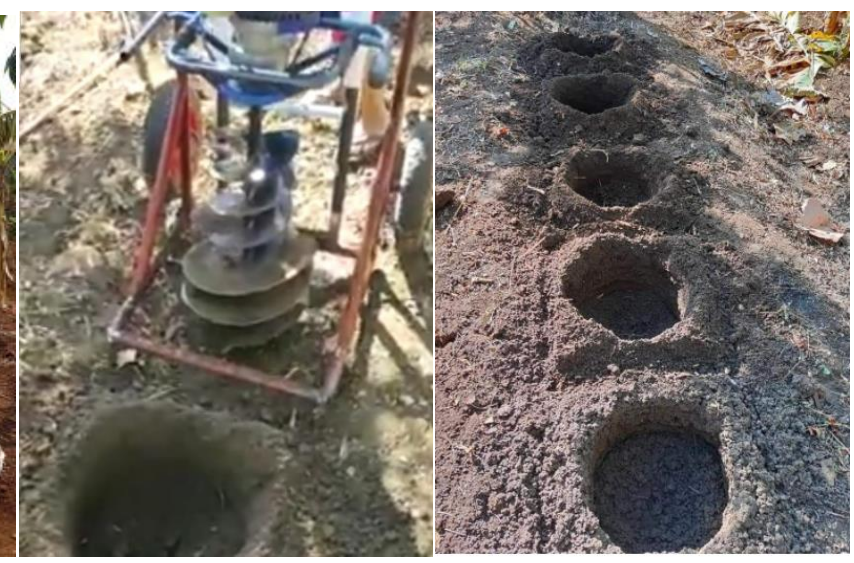

C

D

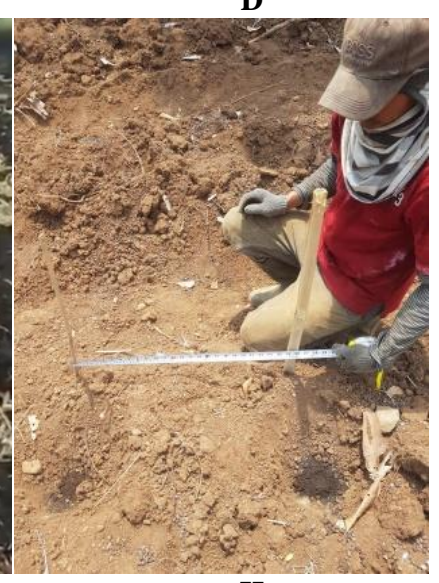

F

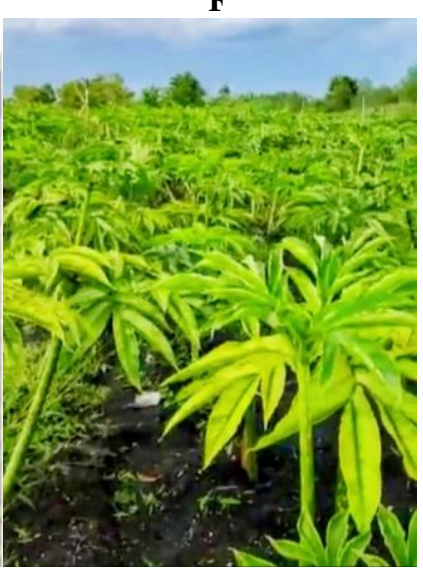

J

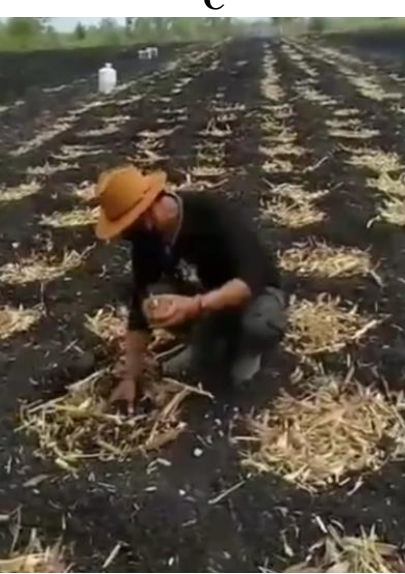

G

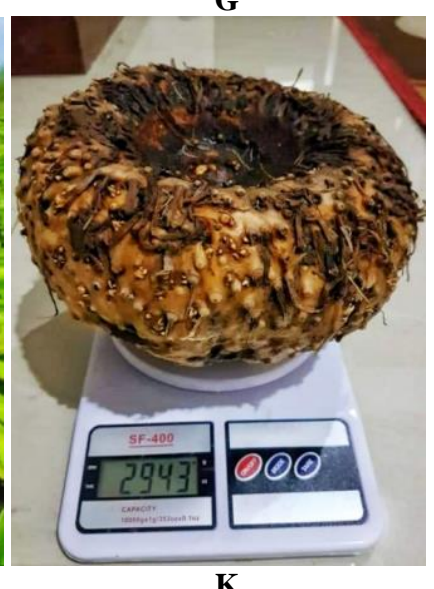

H

Figure 3. Stages of porang (Amorphophallus muelleri) cultivation. A. Soil loosening, B. Making beds, C. Hole making using a drill, D. Planting hole, E. Giving compost/manure, F. Selecting seeds from tubers, G. Planting seeds, H. Measuring planting distance, I. Fertilizing at 27 days after planting, J. Adult Porang plants, K. Harvested tubers

Porang cultivation is quite popular because it is quite adaptive in nature, easy to cultivate, and has high economic value. Porang plants can grow well in the Semarang area known as an area with various ecological conditions. Porang can thrive in cool and highlands such as Limbangan and Gunungpati areas as well as in hot lowlands such as Ngaliyan. However, like other members of Araceae, porang does not require prolonged exposure to the sun, for optimal growth porang must live $40-60 \%$ in the shade. In addition, according to Jansen et al. (1996) porang requires a good drainage system so that water does not stagnate which causes rot in the roots and tubers.
Porang cultivation process is divided into several stages, namely: land preparation, seed preparation, planting, maintenance and harvesting. The land preparation stage includes clearing the planting area and loosening the soil. In the process of loosening the land, farmers usually use hoes, but some farmers (entrepreneurs) use a drill for practical reasons and time efficiency. After the pulverization process, it is continued with the making of raised beds or by the Semarang community it is known as Guludan/Gulutan. These beds are made in addition to making plants look more regular as well as to prevent inundation and facilitate maintenance such as fertilization, weeding and harvesting. 


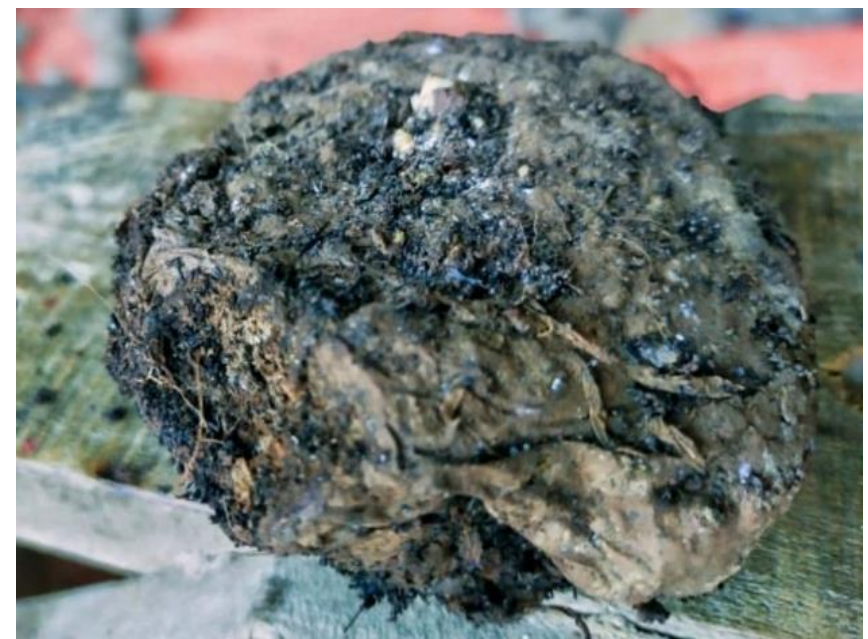

A

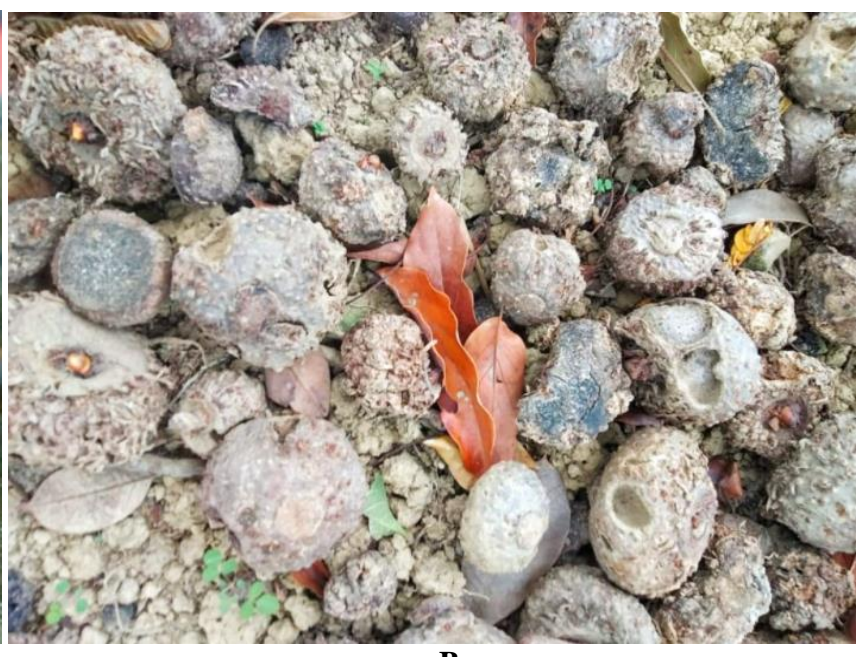

B

Figure 5. The porang tuber is not in a good condition. A. Porang damaged by rot, B. Porang damaged due to wrong storage methods

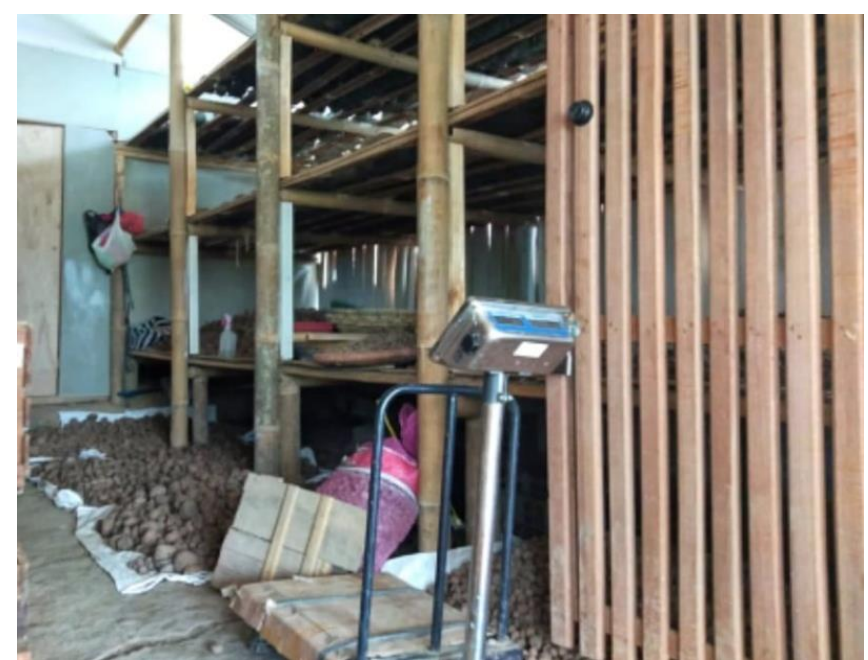

Figure 4. Porang storage area

The next step is making the planting hole and inserting the compost into the hole. Besides compost, some farmers also use a mixture of manure. The seed preparation stage includes selecting good seeds from tubers, bulbils (katak) and seeds (spores). In addition to planting porang in the usual way (one porang grows into one living plant), there are also farmers who plant porang by propagating it. One porang tuber seed from a katak can be multiplied into 4 seeds. There is also a special way for farmers to propagate. First, the porang katak seeds are cut into 4 parts. Then, the seed pieces are soaked in the blended shallot water and closed tightly for $1 / 2$ day, then lifted and aerated. Next, the seeds are smeared with kitchen ash. Finally, when the seeds sprout, only then are they planted in the ground.

In the planting process, the seeds are planted at a depth of $5-7 \mathrm{~cm}$ with a side spacing of $45 \mathrm{~cm}$, and $60 \mathrm{~cm}$ in stripes to allow a more optimal growth of porang. Anturida et al. (2015) stated that spacing in porang cultivation affects plant height, crown width, tuber weight, diameter, and thickness.

The maintenance stage includes fertilization which is done when the porang is 27 days old. The fertilizer commonly used by porang farmers in Semarang and surrounding areas is POC (liquid organic fertilizer). According to the informant, other maintenance is also carried out by controlling weeds, which is usually done several times, especially when the porang plants are 30 days after planting.

Harvesting is usually carried out in the dry season. Porang plants ready for harvest are characterized by leaves that begin to dry out and fall to the ground. According to informants, after planted, porang begins to grow in the 11 th month (November), the 12th month (December), and the 1st month (January). In January, usually, the porang will start to grow tall and the leaves appear. Porang plants will then collapse and wither in the 5th month (May). In the 6th month (June), the porang plants will dry up and the trees will disappear. The 7th month (July) is the time to harvest porang. Porang's growth cycle will repeat in such pattern. Porang lives between 4 to 6 months to live on leaves and 8 months to live without leaves. The porang tubers that are produced really depend on the source of the seeds.

\section{Porang (A. muelleri) storage}

Rotting of porang (A. muelleri) tubers is common. Fungi such as Fusarium solani, Fusarium oxysporum and Botrytis cinerea Pers are the main pathogens that cause the decay (Yu et al. 2015). The rot of porang tubers does not only occur during planting, but also during harvesting and storage. Harvesting done at the wrong time, for example when the age of the porang is too young, will cause rapid decay. This happens because the tubers are still in high water content. In addition, the way of storage can also affect the quality of porang tubers. Therefore a good storage method is needed. 
The way to store porang is not the same as other types of tubers in general. Porang tubers that are not resistant to moisture should be stored using a different method. Porang farmers usually store porang by aerating it. They make a kind of simple wooden shelf which is spaced between one wood and another. The density level is adjusted to the type of porang stored. For katak tubers and spore flowers, the storage place is in a tampah (bamboo tray). Storage in this way is intended to prevent porang from rotting.

According to Adawiah et al. (2019), places for storage of tubers such as above ground level, floor, or shelves affect the physical properties of porang tubers. Storage of porang tubers on the floor causes the hardness of the tubers to decrease significantly, worse than those stored on the ground. The best storage is on a shelf in order to minimize damage to the tubers.

In the storage process, porang are usually grouped by size, ranging from small to large porang. The porang is grouped starting from the porang that is ready for production, tuber seeds, katak seeds, and spores seeds

\section{Treatment of the damaged porang (A.muelleri)}

Not all harvested porang tubers are in a good condition. There are also some tubers that are decayed or damaged. This can be caused by mold or the wrong way of storage. For porang tubers that are affected by fungus, treatment is carried out by spraying Dithane M-45 to remove the fungus in the tubers. Several farmers in Semarang area explained that for tubers that have gone bad after storage, the rotten part will usually be removed, then put on the ground to dry and the shoots continue to grow. In addition, antiseptic solutions are also given to prevent widespread damage.

Although both methods have been attempted, it is not entirely possible to ensure that the tubers are still in good condition. Some are in complete decay during the treatment process. In the 9 th to 11 th months, the porang tubers can be planted together with the perfect tubers (tubers in good condition, not damaged).

\section{Community empowerment for porang (A. muelleri) cultivation}

Besides planting porang for personal business, some porang businessmen socialize porang cultivation to the local community. They invite people in the neighborhood to plant porang because of its many advantages and easy cultivation.

Porang, which is an annual plant and can be planted with an intercropping system, has made it favored by some people. Moreover, currently, porang is a commodity that becomes the target of suppliers in factories and businessmen, even being exported abroad. Porang, which was originally a wild and worthless plant, has now become a sought-after plant and has a very high selling price.

Initially, the community looked for porang plants in the wild or mbolang or pembolang. In one day, they usually get porang with an amount of up to 1 ton. Then the people tried to plant themselves on their own land. Moreover, porang entrepreneurs have proven that they have successfully cultivated porang which has a high selling price.
The process of empowering the local community in cultivating porang is carried out in various ways. Some are by providing seeds, selling seeds at low prices, sharing crops, and so on. This activity is expected to help the community's economy. Moreover, in one harvest farmers can get millions of rupiahs. This can indirectly improve the community's economy

The community gets socialization from porang entrepreneurs who are considered to have knowledge of porang. Then the community planted simultaneously. One of the informants, a porang entrepreneur and farmer from Limbangan village, socializes the movement of 1000 porang seeds for each house (one family) in Limbangan. The same thing was done by porang businessmen from Tuntang area who invited people to plant porang in their neighborhood by giving free seeds to the assisted community members, amounting to 30 people. The entrepreneur then buys the farmers' crops at a suitable market price.

\section{ACKNOWLEDGEMENTS}

The author would like to thank all those who have supported this research, including key informants Ahmad Husain and Raharjo Intar Sahudi who contributed a lot to this paper.

\section{REFERENCES}

Adachi O, Hours RA, Akakabe Y, Arima H, Taneba R, Tanaka J, Kataoka N, Matsushita K, Yakushi T. 2020. Taro koji of Amorphophallus konjac enabling hydrolysis of konjac polysaccharides to various biotechnological interest. Biosci Biotechnol Biochem 84 (10): 21602173. DOI: 10.1080/09168451.2020.1787812.

Adawiah PR Al, Azrianingsih R, Mastuti R. 2019. Effect of Place and Time Storage on the Quality of Tubers Amorphophallus muelleri Blume. J Exp Life Sci. 9 (1): 32-38. DOI: 10.21776/ub.jels.2019.009.01.06.

Anturida Z, Azrianingsih R, Wahyudi D. 2015. Pengaruh Jarak Tanam Terhadap Pertumbuhan Porang (Amorphophallus muelleri Blume.) Pada Fase Pertumbuhan Kedua. J Biotropika. 3 (3): 132-136.

Antweiler C. 1998. Local knowledge and local knowing. an anthropological analysis of contested "cultural products" in the context of development." Anthropos 93 (4/6): 469-494.

Asih NPS, Kurniawan A. 2019. Studi Araceae Bali: Keragaman dan Potensinya. Widya Biol 10 (2): 135-147.

Behera SS, Ray RC. 2017. Nutritional and potential health benefits of konjac glucomannan, a promising polysaccharide of elephant foot yam, Amorphophallus konjac K. Koch: A review. Food Rev Intl 33 (1): 22-43. DOI: 10.1080/87559129.2015.1137310.

Berkes F. 2008. Sacred Ecology. 2nd ed. Routledge, New York.

Chua M, Baldwin TC, Hocking TJ, Chan K. 2010. Traditional uses and potential health benefits of Amorphophallus konjac K. Koch ex $\begin{array}{llll}\text { N.E.Br. J Ethnopharmacol } 128 \text { (2): 268-278. DOI: } & \end{array}$ 10.1016/j.jep.2010.01.021.

Dey YN, Wanjari MM, Kumar D, Lomash V, Jadhav AD. 2016. Curative effect of Amorphophallus paeoniifolius tuber on experimental hemorrhoids in rats. J Ethnopharmacol 192: 183-191. DOI: 10.1016/j.jep.2016.07.042.

DPRD-Jateng. 2020. Komisi B Tertarik Budi Daya Umbi Porang. https://dprd.jatengprov.go.id/2020/12/22/komisi-b-tertarik-budi-dayaumbi-porang/ [Indonesian]

Fang W, Wu P. 2004. Variations of Konjac glucomannan (KGM) from Amorphophallus konjac and its refined powder in China. Food Hydrocoll 18 (1): 167-170. DOI: 10.1016/S0268-005X(03)00044-4. 
Hidayat S. 2019. Short Communication: The study of suweg (Amorphophallus paeoniifolius) and other undergrowth species in teak plantation forest of Temengeng, Blora, Indonesia. Biodiversitas. 20 (1): 37-42. DOI: 10.13057/biodiv/d200105.

Hurkadale PJ, Shelar PA, Palled SG, Mandavkar YD, Khedkar AS. 2012. Hepatoprotective activity of Amorphophallus paeoniifolius tubers against paracetamol-induced liver damage in rats. Asian Pac J Trop Biomed 2 (1, Suppl): S238-S242. DOI: 10.1016/S22211691(12)60167-1.

Impaprasert R, Borompichaichartkul C, Srzednicki G. 2014. A new drying approach to enhance quality of konjac glucomannan extracted from Amorphophallus muelleri. Dry Technol 32 (7): 851-860. DOI: 10.1080/07373937.2013.871728.

Jansen P, van der Wilk C, Hetterscheid W. 1996. Amorphophallus Blume ex Decaisne. In: Flach M, Rumawas F (eds.). PROSEA: Plant Resources of South-East Asia No 9. Plant Yielding Non-seed Carbohydrates. Backhuys Publishers, Leiden.

Khan H, Marya. 2019. Chapter 3.28 - Konjac (Amorphophallus konjac). Nonvitamin and Nonmineral Nutr Suppl 2019: 307-312. DOI 10.1016/B978-0-12-812491-8.00044-8.

Liu P, Zhang S, Zhang X. 1998. Research and Utilization of Amorphophs in China. Plant Divers 20 (10): 1-3.

Lontoh AP, Santosa E, Kurniawati A, Sari M. 2019. Yield evaluation of selected clones apomictic iles-iles (Amorphophallus muelleri Blume) on Second growing period. J Agron Indones. 47 (2): 171-179.

Mohammadpour S, Amini MR, Shahinfar H, Tijani AJ, Shahavandi M, Ghorbaninejad P, Djafarian K, Shab-Bidar S. 2020. Effects of glucomannan supplementation on weight loss in overweight and obese adults: A systematic review and meta-analysis of randomized controlled trials. Obes Med 19: 100276. DOI: 10.1016/j.obmed.2020.100276

Mubarok ASFQR, Santoso I. 2018. Community response to Amorphophallus sp. Agroindustrial empowerment using partial least square. Habitat 29 (3): 99-105

Mutaqin AZ, Kurniadie D, Iskandar J, Nurzaman M, Partasasmita R. 2020. Ethnobotany of suweg, Amorphophallus paeoniifolius: Utilization and cultivation in West Java, Indonesia. Biodiversitas 21 (4): 1635-1644. DOI: 10.13057/biodiv/d210444.

Nair A, Chattopadhyay D, Saha B. 2019. Chapter 17 - Plant-Derived Immunomodulators. In: New Look to Phytomedicine Advancements in Herbal Products as Novel Drug Leads. Academic Press, New York. DOI: 10.1016/B978-0-12-814619-4.00018-5.

Pemprov-Jateng. 2020. Potensi Menjanjikan, Kudus Dorong Budidaya Porang. https://jatengprov.go.id/beritadaerah/potensi-menjanjikankudus-dorong-budidaya-porang/ [Indonesian]

Pertanian-Jateng. 2020. Makin Bersinar Potensi Porang Jawa Tengah di Mancanegara. http://semarang.karantina.pertanian.go.id/makinbersinar-potensi-porang-jawa-tengah-di-mancanegara/ [Indonesian]

Purcell TW. 1998. Indigenous Knowledge and Applied Anthropology: Questions of Definition and Direction. Hum Organ 57 (3): 258-272.

Raj S, Gothandam KM. 2014. Hepatoprotective effect of polyphenols rich methanolic extract of Amorphophallus commutatus var. wayanadensis against $\mathrm{CCl}_{4}$ induced hepatic injury in swiss albino mice. Food Chem Toxicol 67: 105-112. DOI: 10.1016/j.fct.2014.02.028.
Saleh N, Rahayuningsih SA, Radjit BS, Ginting E, Harnowo D, Mejaya IMJ. 2015. Tanaman Porang: Pengenalan, Budidaya, dan Pemanfaatannya. Pusat Penelitian dan Pengembangan Tanaman Pangan, Bogor. [Indonesian]

Santosa E, Sugiyama N, Hikosaka S, Kawabata S. 2003. Cultivation of Amorphophallus muelleri Blume in Timber Forests of East Java, Indonesia. Jpn J Trop Agr. 47 (3): 190-197.

Santosa E, Sugiyama N, Kurniawati A, Lontoh AP, Sari M, Krisantini K. 2018. Variation in floral morphology of agamosporous (Amorphophallus muelleri Blume) in natural and gibberellin-induced flowering. J Appl Hortic 20 (1): 15-23.

Shi X-D, Yin J-Y, Cui SW, Wang Q, Wang S-Y, Nie S-P. 2020. Plantderived glucomannans: Sources, preparation methods, structural features, and biological properties. Trends Food Sci Technol 99: 101116. DOI: 10.1016/j.tifs.2020.02.016.

Shi X-D, Yin J-Y, Zhang L-J, Huang X-J, Nie S-P. 2019. Studies on Oacetyl-glucomannans from Amorphophallus species: Comparison of physicochemical properties and primary structures. Food Hydrocoll 89: 503-511. DOI: 10.1016/j.foodhyd.2018.11.013.

Sirotkin A V. 2021. Can konjac (Amorphophallus konjac K. Koch) and it constituent glucomannan be useful for treatment of obesity? Obes Med 24: 100343. DOI: 10.1016/j.obmed.2021.100343

Sugiyama N, Santosa E. 2008. Edible Amorphophallus in Indonesia. Gadjah Mada University Press, Yogyakarta.

Sumarwoto S, Maryana M. 2011. Pertumbuhan bulbil iles-iles (Amorphophallus muelleri Blume) berbagai ukuran pada beberapa jenis media tanam. J Ilmu Kehutanan 5 (2): 91-98.

Susanto E. 2020. Pengembangan Talas Dan Iles-Iles: Komoditas Lokal Mendukung Ekspor, Webinar Departemen Agronomi dan Hortikultura Fakultas Pertanian. Institut Pertanian Bogor, Bogor [Indonesian]

Vasques CAR, Rossetto S, Halmenschlager G, Linden R, Heckler E, Fernandez MSP, Alonso JLL. 2008. Evaluation of the pharmacotherapeutic efficacy of Garcinia cambogia plus Amorphophallus konjac for the treatment of obesity. Phytother Res 22 (9): 1135-1140. DOI: 10.1002/ptr.2323.

Widjaja E, Rahayuningsih Y, Rahajoe JS, Ubaidillah R, Maryanto I, Walujo EB, Semiadi G. 2014. The Current biodiversity of Indonesia 2014. Kekinian Keanekaragaman Hayati Indonesia 2014. LIPI Press, Jakarta. [Indonesian]

Wigoeno Y, Azrianingsih R, Roosdiana A. 2013. Analisis Kadar Glukomanan Pada Umbi Porang (Amorphophallus muelleri Blume) Menggunakan Refluks Kondensor. Biotropika. 1 (5): 231-235. [Indonesian]

Yanuriati A, Marseno DW, Rochmadi, Harmayani E. 2017. Characteristics of glucomannan isolated from fresh tuber of Porang (Amorphophallus muelleri Blume). Carbohydr Polym 156: 56-63. DOI: 10.1016/j.carbpol.2016.08.080.

Yu L, Zhao J, Liu J, Wu X, Wang D, Xu S, Sigismond GS. 2015. Identification of postharvest pathogens of Amorphophallus muelleri and indoor screening of fungicides. J Agric Sci Technol A (5): 577584. DOI: 10.17265/2161-6256/2015.07.002. 